Abstracta Iranica Abstranica

Revue bibliographique pour le domaine irano-aryen

Volume 28 | 2007

Comptes rendus des publications de 2005

\title{
The Yezidis. Foreword by Philip Kreyenbroek, London, Saqi books, 96 p., $35 \mathrm{pl}$.
}

\section{Christine Allison}

\section{(2) OpenEdition}

1 Journals

\section{Édition électronique}

URL : http://journals.openedition.org/abstractairanica/12292

DOI : 10.4000/abstractairanica. 12292

ISSN : 1961-960X

Éditeur :

CNRS (UMR 7528 Mondes iraniens et indiens), Éditions de l'IFRI

Édition imprimée

Date de publication : 15 mai 2007

ISSN : 0240-8910

Référence électronique

Christine Allison, «The Yezidis. Foreword by Philip Kreyenbroek, London, Saqi books, 96 p., 35 pl. », Abstracta Iranica [En ligne], Volume 28 | 2007, document 256, mis en ligne le 18 septembre 2007, consulté le 25 septembre 2020. URL : http://journals.openedition.org/abstractairanica/12292 ; DOI : https://doi.org/10.4000/abstractairanica.12292

Ce document a été généré automatiquement le 25 septembre 2020.

Tous droits réservés 


\title{
The Yezidis. Foreword by Philip Kreyenbroek, London, Saqi books, 96 p., 35 pl.
}

\author{
Christine Allison
}

1 An introduction to Yezidism for the general reader has been needed for some time. This book, its straightforward style notwithstanding, is based on both fieldwork and wide research and is a reliable source, giving an accurate description of the Yezidi community in Iraq and the period around the second Gulf War. It is also well illustrated. The introductory chapter describes the Yezidis' historical and geographical background, the main community centres in Iraq (Sheikhan and Sinjar) and the Yezidis' situation as a minority religion within the Kurdish autonomous zone. The second deals with their highly syncretistic religion, its caste system, its rules of conduct, and recent changes in religious habits and attitudes brought about by higher literacy levels and mass media. The chapter on festivals focuses mainly on the Autumn Feast of the Assembly (which figures in many of the colour plates). The final two chapters describe how the Yezidis fared during and after the Second Gulf War. These are followed by a useful select bibliography and an index. More Lady Drower than Monsieur Lescot, this book has a lively tone and a 'warts and all' style of description - which includes everything from the unpopularity of the princely family, the taking of alms by men of religion from the commoners, bathroom provision in the Sacred Valley of Lalesh, the replacement of epic songs by Mr Bean as a popular entertainment, to Yezidi anxieties that as a religious minority they might become a terrorist target. This may not be to the taste of all, but the author never claims to be other than an outsider, and the whole is informed by a strong sympathy for the Yezidi community, and a concern that a very old tradition is changing so rapidly that much will soon be lost. Beneath the good humour, this is a serious general book about Yezidism. 
INDEX

Thèmes : 6.3. Autres religions

\section{AUTEURS}

CHRISTINE ALLISON

INaLCO / Mondes iranien et indien - Paris 